\title{
Perkembangan Sel Endometrium Domba setelah Inkubasi dalam Kolagenase dan Dikultur In Vitro dengan Estradiol dan Progesteron
}

\author{
(DEVELOPMENT OF OVINE ENDOMETRIAL CELL \\ AFTER INCUBATING IN COLLAGENASE AND CULTURED \\ IN MEDIUM WITH ESTRADIOL AND PROGESTERONE IN VITRO) \\ Ananda ${ }^{1}$, Ekayanti Mulyawati Kaiin ${ }^{2}$, \\ Ni Wayan Kurniani Karja ${ }^{1,3}$, Mohamad Agus Setiadi ${ }^{1,3^{*}}$ \\ ${ }^{1}$ Program Studi Biologi Reproduksi, \\ Sekolah Pascasarjana, Institut Pertanian Bogor, \\ ${ }^{2}$ Pusat Penelitian Bioteknologi, Lembaga Ilmu Pengetahuan Indonesia, \\ Jl. Raya Bogor km 46, Cibinong, Jawa Barat, Indonesia, 16911 \\ ${ }^{3}$ Departemen Klinik Reproduksi dan Patologi, \\ Fakultas Kedokteran Hewan, Institut Pertanian Bogor, \\ Jl. Agatis Kampus IPB Dramaga, Bogor, Jawa Barat, Indonesia, 16680 \\ Telp: (0251) 8626368, Fax: (0251) 8629461 \\ *Penulis untuk korespondensi: setiadi03@yahoo.com
}

\begin{abstract}
The aim of the present study was to determine the optimal incubation time of collagenase on concentration, viability, quality of endometrial cell culture, and the role of estradiol and progesterone on ovine endometrial cells proliferation. Endometrium minced was incubated into collagenase with different duration of time: 1 hour, 3 hours, and 6 hours repectively. Cell concentration and viability were calculated after incubation. The quality of cell culture was observed on $1 \mathrm{st}$, $3 \mathrm{rd}$, and $5^{\text {th }}$ day after seeding. The best incubation result was then continued with the addition of the $\mathrm{E} 2(100 \mathrm{pg} /$ $\mathrm{mL}), \mathrm{P} 4(100 \mathrm{ng} / \mathrm{mL}), \mathrm{E} 2: \mathrm{P} 4(100 \mathrm{pg} / \mathrm{mL}: 10 \mathrm{ng} / \mathrm{mL})$, and E2:P4 (10 pg/mL : $100 \mathrm{ng} / \mathrm{mL})$ into the culture medium. After nine days, cell culture was harvested by trypsinization. Concentration and cell viability were analyzed using analysis of variance, followed by Duncan test. Quality of endometrial cell culture was analyzed descriptively. Results showed that there was a significant decreased in the concentration and cell viability obtained in each treatment of collagenase incubation time and optimum treatment of endometrial cell culture was found at 3 hours. Experiment on culture of endometrial cell revealed that proliferation rate treated by E2 and P4 was better then control $(\mathrm{P}<0.05)$. Futhermore, additional of $\mathrm{E} 2$ into the culture medium even $\mathrm{E} 2$ alone $(100 \mathrm{pg} / \mathrm{mL}$ or higher E2 combination with $\mathrm{P} 4(100 \mathrm{pg} / \mathrm{mL}: 10 \mathrm{ng} / \mathrm{mL})$ showed better proliferation rate than $\mathrm{P} 4$ alone $(100 \mathrm{ng} / \mathrm{mL})$ or higher $\mathrm{P} 4$ combination $(10 \mathrm{pg} / \mathrm{mL}: 100 \mathrm{ng} / \mathrm{mL})$. In conclusion, suplementation of $100 \mathrm{pg} / \mathrm{mL}$ of estradiol (E2) could support better proliferation of ovine endometrial cells in vitro.
\end{abstract}

Keywords: endometrial cells; cells culture; collagenase; estradiol; progesterone

\section{ABSTRAK}

Penelitian ini bertujuan untuk menentukan waktu inkubasi yang optimal enzim kolagenase terhadap konsentrasi, viabilitas, kualitas kultur sel endometrium, serta peran estradiol dan progesteron pada proliferasi sel endometrium domba. Cacahan endometrium diinkubasi ke dalam kolagenase dengan durasi waktu yang berbeda: 1 jam, 3 jam, dan 6 jam. Konsentrasi sel dan viabilitas dihitung setelah inkubasi. Kualitas kultur sel diamati pada hari ke-1, ke-3, dan ke-5 setelah kultur. Hasil inkubasi terbaik kemudian dilanjutkan dengan penambahan E2 (100 pg/ $\mathrm{mL}), \mathrm{P} 4(100 \mathrm{ng} / \mathrm{mL}), \mathrm{E} 2: \mathrm{P} 4(100 \mathrm{pg} / \mathrm{mL}: 10 \mathrm{ng} / \mathrm{mL})$, dan E2:P4 (10 pg/mL : $100 \mathrm{ng} / \mathrm{mL}) \mathrm{ke}$ dalam medium kultur. Setelah sembilan hari, sel dipanen dengan cara tripsinisasi. Konsentrasi dan 
viabilitas sel dianalisis menggunakan sidik ragam, dilanjutkan dengan uji Duncan. Kualitas kultur sel endometrium dianalisis secara deskriptif. Hasil penelitian menunjukkan bahwa terdapat penurunan yang signifikan terhadap konsentrasi dan viabilitas sel yang diperoleh pada perlakuan waktu inkubasi kolagenase dan perlakuan optimum kultur sel endometrium ditunjukkan pada perlakuan 3 jam. Percobaan pada kultur sel endometrium mengungkapkan bahwa tingkat proliferasi sel endometrium yang disuplementasi oleh $\mathrm{E} 2$ dan $\mathrm{P} 4$ lebih baik daripada kontrol $(\mathrm{P}<0.05)$. Selanjutnya, penambahan E2 ke dalam medium kultur baik dengan E2 tunggal ( $100 \mathrm{pg} / \mathrm{mL})$ atau kombinasi E2 yang lebih tinggi dengan P4 $(100 \mathrm{pg} / \mathrm{mL}: 10 \mathrm{ng} / \mathrm{mL})$ menunjukkan tingkat proliferasi yang lebih baik daripada P4 tunggal $(100 \mathrm{ng} / \mathrm{mL})$ atau kombinasi $\mathrm{P} 4(10 \mathrm{pg} / \mathrm{mL}: 100 \mathrm{ng} / \mathrm{mL})$. Dapat disimpulkan bahwa suplementasi $100 \mathrm{pg} / \mathrm{mL}$ estradiol (E2) dapat mendukung proliferasi sel endometrium domba yang lebih baik secara in vitro.

Kata-kata kunci: sel endometrium; kultur sel; kolagenase; estradiol; progesteron

\section{PENDAHULUAN}

Endometrium adalah salah satu lapisan pada uterus yang terus mengalami pertumbuhan dan diferensiasi dalam merespons hormon ovarium dalam peranannya sebagai media implantasi blastosis (Giudice 2003) dan meregenerasi jaringan endometrium untuk kembali bersiklus apabila tidak terjadi implantasi (Maruyama dan Yoshimura 2008). Terdapat dua jaringan utama penyusun endometrium yang sangat berperan penting terhadap keberhasilan endometrium dalam menjalankan fungsinya, yaitu jaringan epitel dan jaringan stroma (Senger 2003). Keberhasilan implantasi dipengaruhi oleh kemampuan penerimaan dan kesiapan jaringan epitel dan jaringan stroma endometrium (Simon et al., 2000; Diedrich et al., 2007).

Secara umum endometrium mengalami berbagai perubahan meliputi proliferasi dan apoptosis sel sesuai dengan siklus reproduksinya (Senger, 2003). Kemampuan proliferasi dan regenerasi jaringan endometrium diduga berkaitan dengan keberadaan sel progenitor endometrium yang terdapat pada lapisan basal endometrium (Gargett, 2007). Kemampuan ini dapat dimanfaatkan sebagai terapi sel pada kasus disfungsi endometrium. Terapi sel dan jaringan endometrium sebelumnya telah dilakukan untuk mencari solusi terhadap kasus endometriosis (Hull et al., 2005). Nisolle et al . (2000) sebelumnya telah melakukan percobaan transplantasi jaringan endometrium yang dibiakkan secara in vitro pada mencit. Namun demikian, penggunaan sel endometrium membutuhkan sumber sel endometrium yang akan ditransplantasikan dalam jumlah yang memadai.

Salah satu metode yang umum dipakai untuk mendapatkan sel dari jaringan hidup adalah dengan menggunakan reaksi enzimatis. Enzim yang sering digunakan dalam memperoleh sel yang akan dikultur adalah enzim kolagenase. Kolagenase adalah enzim yang dapat memecah domain triple helix dari kolagen (Daboor et al., 2010) sehingga menjadikan sel terpisah dari sel yang lain tanpa merusak membran sel (Alipour et al., 2016). Freshney (2005) melaporkan bahwa penggunaan enzim kolagenase merupakan salah satu teknik isolasi sel terbaik yang digunakan dalam mengisolasi sel epitel dan sel stroma.

Beberapa peneliti lainnya juga menggunakan enzim kolagenase untuk mengisolasi sejumlah sel seperti sel kondrosit (Yonenaga et al., 2017), sel mesenkim pada tali pusar anjing (Lee et al., 2013), sel Leydig pada tikus (Kaiin et al., 2013) sel germinal pada testis kuda (Jung dan Yoon 2016), sel Schwann (Jin et al., 2008) serta progenitor sel otot (Ishii et al., 2017). Sementara itu, penelitian tentang lama waktu inkubasi enzim kolagenase untuk mendapatkan sejumlah sel endometrium bervariasi baik tentang lama inkubasi maupun hasil yang dilaporkan seperti pada kelinci dengan lama waktu inkubasi 1,5 jam (Mulholland et al., 1988), sapi dengan lama waktu inkubasi dua jam (Kimmins et al., 2003), mencit dengan lama waktu inkubasi 20-30 menit (Wewer et al., 1986) hingga 1,5 jam (Janzen et al., 2013), anjing dengan lama waktu inkubasi 4-6 jam (Bartel et $a l ., 2013)$, babi dengan lama waktu inkubasi yang berbeda yaitu satu jam (Wang et al., 2000), 1,5 jam (Blitek dan Ziecik, 2004), dan 2 jam (Aldarmahi, 2017).

Secara in vivo pengaturan endometrium tergantung pada hormon steroid (Zhu et al., 2014). Endometrium pada hewan dan manusia cendurung memiliki persamaan dalam merespons hormon steroid (Janzen et al., 2013). Pada manusia dan hewan primata, penurunan 
progesteron pada fase luteal menyebabkan menstruasi (Brosens dan Gellersen 2006), sedangkan pada hewan dengan siklus estrus, penurunan progesteron menyebabkan sel endometrium mengalami apoptosis dan reabsorbsi (Wood et al., 2007). Restorasi endometrium kembali dimulai pada siklus berikutnya seiring dengan kenaikan jumlah estrogen pada fase folikuler. Estrogen diketahui menyebabkan proliferasi sel-sel endometrium sehingga endometrium kembali mengalami regenerasi (Saleh et al., 2011).

\section{METODE PENELITIAN}

Pengambilan Sampel. Uterus dikoleksi pada fase folikular dengan memperhatikan terdapatnya folikel dominan pada ovarium. Uterus selanjutnya segera dibilas dengan menggunakan $\mathrm{NaCl}$ fisiologis kemudian ditransportasikan ke laboratorium dengan menggunakan termos Cito Warm Water Thaw (Minitube) yang telah berisi $\mathrm{NaCl}$ fisiologis dan mengandung $100 \mathrm{IU} / \mathrm{mL}$ penisilin (Sigma, P3032) dan 0,1 mg/mL streptomisin (Sigma, S6501) pada suhu $38^{\circ} \mathrm{C}$.

Koleksi dan Inkubasi Kolagenase. Teknik koleksi sel endometrium dilakukan dengan menggunakan metode enzimatis yang dimodifikasi dari Freshney (2005). Uterus dibilas dengan menggunakan Dulbecco's Phospate Buffered Saline (DPBS, Sigma, D8537) yang mengandung $62,5 \mu \mathrm{g} / \mathrm{mL}$ gentamisin (Sigma, G-1272). Selanjutnya uterus dipotong secara longitudinal, bagian endometrium dan miometrium dipisahkan. Bagian endometrium yang diperoleh dibilas kembali dengan menggunakan DPBS (Sigma, D-8537) yang mengandung 62,5 $\mathrm{\mu g} / \mathrm{mL}$ gentamisin (Sigma, G1272) dan dicacah dengan menggunakan gunting dan pisau bedah steril. Hasil cacahan endometrium selanjutnya dimasukkan kedalam cawan petri steril dan diinkubasi dengan $1 \mathrm{mg} /$ mL enzim kolagenase tipe I (Sigma, C-0130) dalam inkubator (Thermo Scientific) selama 1 jam, 3 jam, atau 6 jam. Selanjutnya dilakukan proses pipetting untuk memastikan sel terdisintegrasi dan disaring dengan menggunakan Sterile Nylon Filter $40 \mu \mathrm{m}$ (Falcon, 2340). Proses enzimatis dihentikan dengan menggunakan DPBS (Sigma, D-8537) yang mengandung 1\% New Born Calf Serum (NBCS, Gibco, 26010-074) dan disentrifugasi selama lima menit pada kecepatan $250 \mathrm{~g}$ sebanyak tiga kali. Pellet dikoleksi dan diresuspensi dengan $5 \mathrm{~mL}$ Dulbecco's modified Eagle's medium (DMEM, Sigma, D-5523) yang mengandung 10\% NBCS (Gibco, 26010-074) dan disentrifugasi kembali. Pellet diresuspensi dalam 1 mL DMEM (Sigma, D-5523) dan dilakukan penghitungan konsentrasi dan viabilitas sel pada kamar hitung hemositometer improve Neaubeauer dengan rumus, konsentrasi sel = jumlah sel dalam lima kotak x 25 x 104; sedangkan viabilitas sel $=[($ jumlah sel hidup $) \mathrm{x}$ (total seluru sel) $^{-1}$ ] x $100 \%$.

Sel yang diperoleh dikultur dengan konsentrasi $3 \times 10^{6} \mathrm{sel} / \mathrm{mL}$ pada cell culture dish $35 \mathrm{~mm}$ (Corning, 430165) yang telah di-coating dengan 0,1\% gelatin (Sigma, G-9391) di dalam inkubator (Thermo Scientific) pada suhu $38^{\circ} \mathrm{C}$ dan $5 \% \mathrm{CO}_{2}$.

Suplementasi Estradiol dan/atau Progesteron. Sebanyak $10^{6} \mathrm{sel} / \mathrm{mL}$ suspensi sel endometrium diambil dengan metode terbaik pada tahap pertama dikoleksi dan dikultur dengan penambahan hormon estradiol (E2, Sigma, E-4389) dan progesteron (P4, Sigma, P0130) dengan masing-masing perlakuan media kultur sebagai berikut; (1) DMEM + 10\% NBCS (mDMEM) sebagai control; (2) $\mathrm{mDMEM}+100$ $\mathrm{pg} / \mathrm{mL} \mathrm{E} 2$; (3) mDMEM + $100 \mathrm{ng} / \mathrm{mL}$ P4; (4) $\mathrm{mDMEM}+100 \mathrm{pg} / \mathrm{mL}$ E2 dan $10 \mathrm{ng} / \mathrm{m}$ P4, dan (5) $\mathrm{mDMEM}+10 \mathrm{pg} / \mathrm{mL}$ E2 dan $100 \mathrm{ng} / \mathrm{mL}$ P4 Selanjutnya dilakukan inkubasi pada suhu $38^{\circ} \mathrm{C}$ dengan $5 \% \mathrm{CO}_{2}$. Sel yang telah konfluen pada sembilan hari kultur, kemudian dipanen dengan menggunakan 0,2\% tripsin-EDTA (Gibco, 15400054) pada suhu ruang selama 1-2 menit. Sel yang diperoleh kemudian disentrifugasi pada kecepatan $250 \mathrm{~g}$ selama lima menit dan diresuspensi dalam $1 \mathrm{~mL}$ mDMEM. Selanjutnya dilakukan penghitungan konsentrasi dan viabilitas sel.

Analisis Data. Data yang diperoleh dianalisis menggunakan software SPSS 16.0 dengan ulangan sebanyak sembilan kali pada perlakuan kolagenase, serta lima kali ulangan untuk perlakuan penambahan hormone. Data kuantitatif (variable dependen) diuji kemaknaanya terhadap pengaruh kelompok perlakuan (variable independence). Urutan uji diawali dengan uji analysis of variance. Hasil uji yang menunjukkan signifikan $(p<0,05)$, terhadap data tersebut dilanjutkan dengan uji Duncan. 
Tabel 1. Perbandingan kualitas sel endometrium terhadap paparan enzim kolagenase dengan lama waktu inkubasi yang berbeda

\begin{tabular}{lccc}
\hline Parameter $(\mathrm{n}=9)$ & \multicolumn{3}{c}{ Lama inkubasi enzim kolagenase } \\
\cline { 2 - 4 } & 1 jam & 3 jam & 6 jam \\
\hline $\begin{array}{l}\text { Konsentrasi } \\
\text { juta sel/mL) }\end{array}$ & $12,17 \pm 0,47 \mathrm{a}$ & $8,68 \pm 0,37 \mathrm{~b}$ & $6,24 \pm 0,95 \mathrm{c}$ \\
Viabilitas(\%) & $54,64 \pm 5,26 \mathrm{a}$ & $45,52 \pm 4,53 \mathrm{~b}$ & $41,79 \pm 3,89 \mathrm{~b}$ \\
\hline Keterangan: & abc & Huruf berbeda yang mengikuti angka menunjukkan perbedaan nyata $(\mathrm{P}<0,05)$.
\end{tabular}

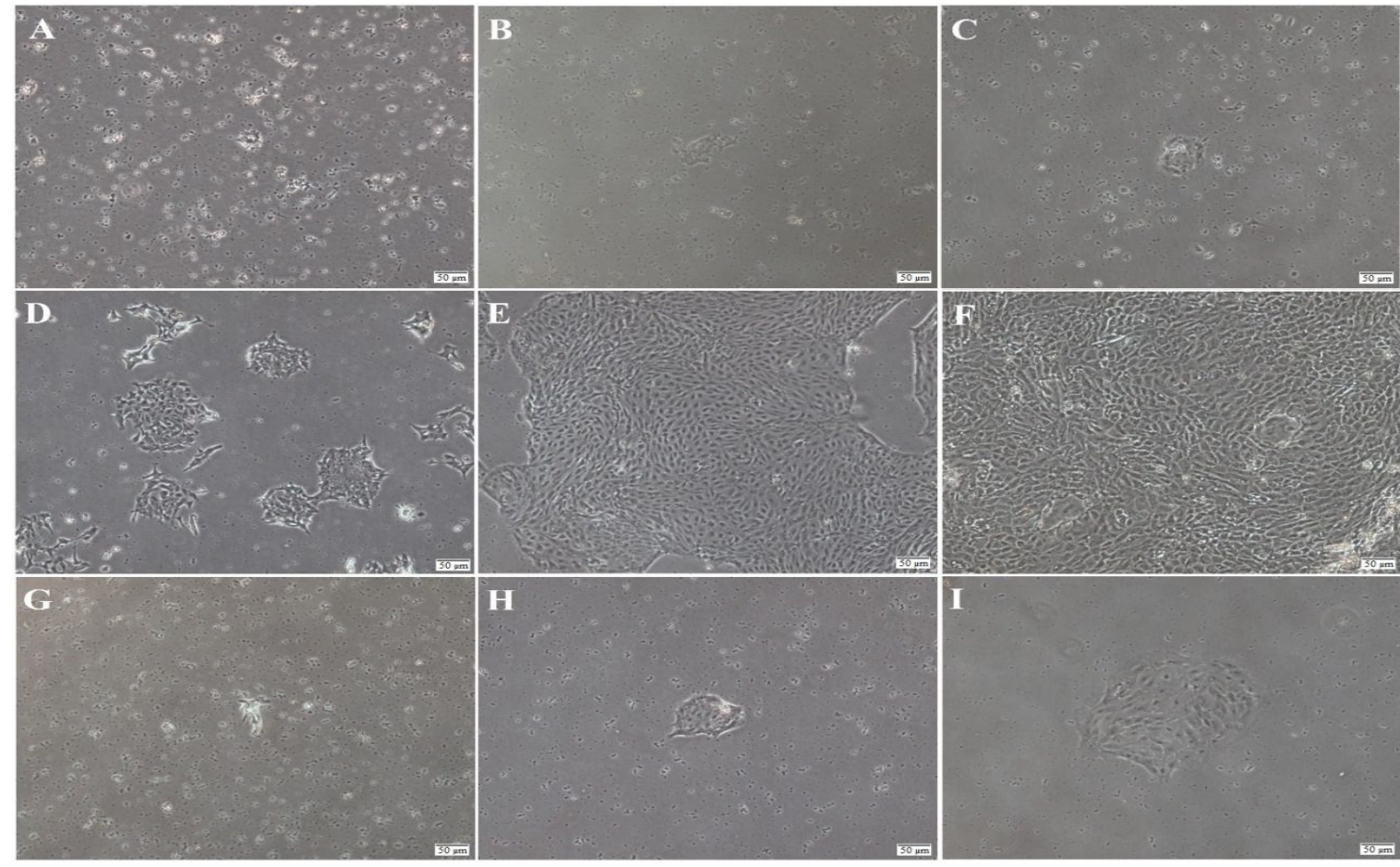

Gambar 1. Kultur sel endometrium domba. A. inkubasi kolagenase 1 jam setelah 24 jam kultur. B. inkubasi kolagenase 1 jam setelah 3 hari kultur. C. inkubasi kolagenase 1 jam setelah 5 hari kultur. D. inkubasi kolagenase 3 jam setelah 24 jam kultur. E. inkubasi kolagenase 3 jam setelah 3 hari kultur. F. inkubasi kolagenase 3 jam setelah 5 hari kultur. G. inkubasi kolagenase 6 jam setelah 24 jam kultur. H. inkubasi kolagenase 6 jam setelah 3 hari kultur. I. inkubasi kolagenase 6 jam setelah 5 hari kultur.
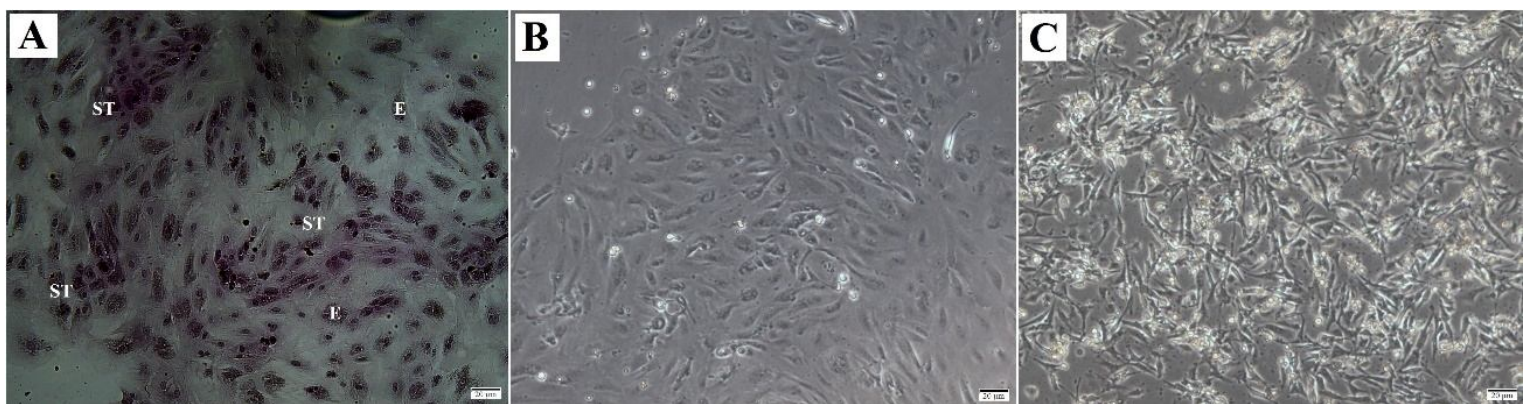

Gambar 2. Kultur sel endometrium dengan pewarnaan Hematoksilin-Eosin. A. Sebaran sel epitel (E) dan sel stroma (ST) pada pewarnaan hematoksilin-eosin, B. koloni sel epitel, C. koloni sel stroma 

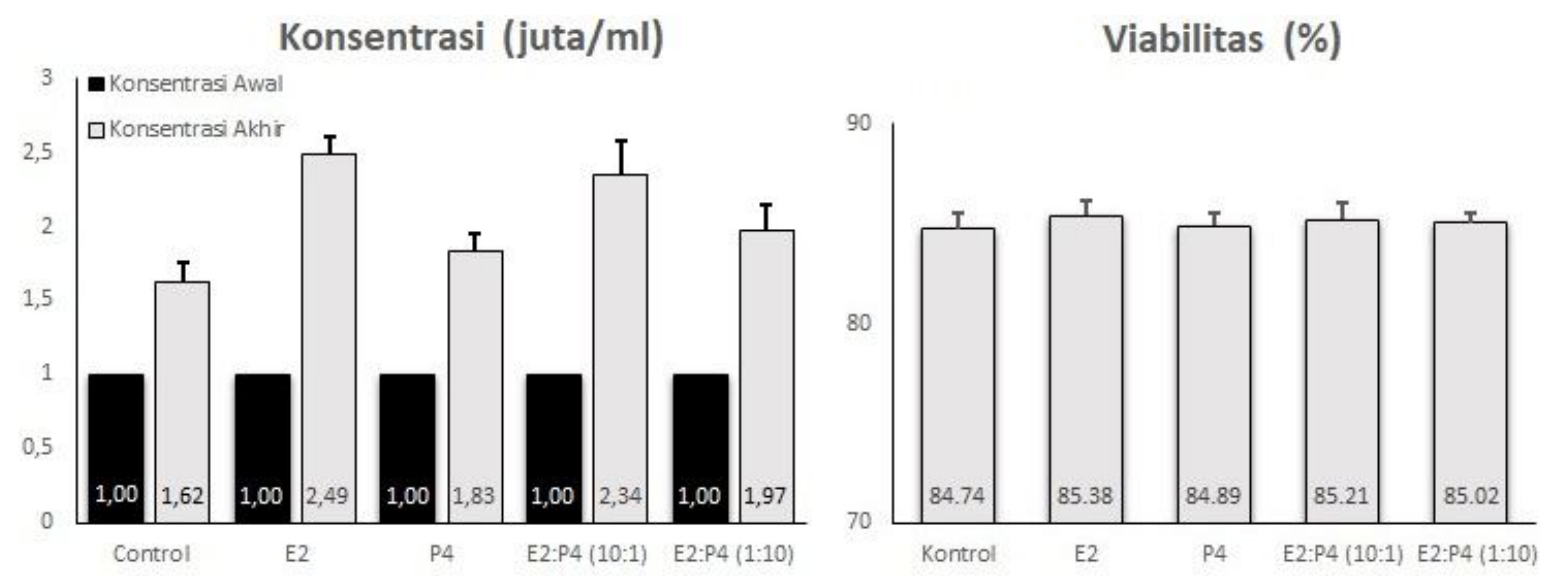

Gambar 3. Proliferasi sel endometrium (in vitro) pasca pemberian hormon estradiol dan/atau progesteron selama 10

\section{HASIL DAN PEMBAHASAN}

Konsentrasi, Viabilitas, dan Perkembangan Sel Endometrium Secara In Vitro Pascainkubasi Enzim Kolagenase

Hasil yang diperoleh menunjukkan terjadinya penurunan secara signifikan $(\mathrm{p}<0,05)$ kualitas sel yang dikoleksi pascainkubasi dengan enzim kolagenase. Konsentrasi sel hidup yang diperoleh mengalami penurunan sejalan dengan semakin lamanya waktu inkubasi. Hal yang sama juga terlihat pada persentase viabilitas sel yang mengalami penurunan seiring dengan semakin lamanya waktu inkubasi yang digunakan (Tabel 1).

Kolagenase adalah enzim yang dihasilkan dari Clostridium histolyticum (Bond dan Wart 1984) yang merupakan enzim hidrolitik nonsitotoksik dan bekerja secara maksimum pada kisaran $\mathrm{pH}$ 6,5-7,8 dalam medium isotonis (Limon et al., 1986) serta mampu mendegradasi kolagen (Toyoshima et al., 2001). Bakteri $C$. histolyticum memproduksi dua jenis kolagenase: kolagenase 1 (clostridiopeptidase A) dan kolagenase 2 (clostridiopeptidase B). Limon $e t$ al. (1986) menyatakan bahwa enzim kolagenase merupakan enzim non-sitotoksik yang memecah protein matriks ekstraselular tanpa merusak membran sel. Namun, kolagenase murni yang diisolasi dari bakteri diketahui tidak efisien dalam memisahkan jaringan karena tingginya konsentrasi protein non kolagen dan makromolekul lain yang ditemukan dalam matriks ekstraseluler pada jaringan konektif dan jaringan epitel, sehingga diperlukan kombinasi dengan enzim protease lainnya (Worthington Biochemical Corporations).
Beberapa tipe kolagenase yang umum digunakan untuk mendapatkan sejumlah sel hewan, seperti kolagenase tipe I untuk mengisolasi sel epitel, sel stroma, sel adrenal, sel paru-paru, dan sel lemak; tipe II untuk mengisolasi sel jantung, sel tiroid, sel kelenjar ludah, sel hati, sel tulang, sel tulang rawan; tipe IV untuk mengisolasi sel reseptor insulin (Gibco Life Technologies Corporation). Pada penelitian ini enzim yang digunakan adalah enzim kolagenase tipe I yang spesifik dalam mengisolasi sel epitel dan sel stroma yang merupakan jaringan utama pada endometrium. Kolagenase tipe I memiliki komposisi yang terdiri dari beberapa enzim protease lainnya selain kolagenase seperti caseinase, clostripain, dan tripsin (Sigma C-0130). Laporan hasil penelitian Pevet et al. (1976) menunjukkan bahwa tripsin memprovokasi perubahan ultrastruktural pada permukaan sel, melepaskan glikoprotein dan gula dari membran sel serta mencegah pembentukan glikoprotein yang berdampak kepada kerusakan membran sel. Huang et al. (2010) mengungkapkan hal yang sama bahwa tripsin memberikan dampak yang signifikan terhadap jumlah apoptosis sel subkultur, sehingga waktu inkubasi yang optimum penting diperhatikan untuk menghindari apoptosis pada sel.

Hasil yang berbeda diperoleh terhadap kultur in vitro sel endometrium domba pada masing-masing perlakuan lama waktu inkubasi enzim kolagenase (Gambar 1). Pertumbuhan sel tampak lebih baik pada perlakuan dengan lama waktu inkubasi kolagenase tiga jam, pada kultur tersebut sel terlihat membentuk koloni setelah 24 jam kultur dan terus tumbuh hingga kultur hari ke-5. Sementara itu pertumbuhan 
sel sangat rendah pada perlakuan waktu inkubasi kolagenase 6 jam dan baru membentuk koloni pada hari ke-5. Panjang waktu inkubasi yang digunakan diduga mengakibatkan sejumlah enzim protease pada kolagenase tipe I merusak membran sel dan menyebabkan apoptosis pada sel (Huang et al., 2010), sedangkan untuk inkubasi kolagenase satu jam hanya tampak beberapa sel fibroblast dan beberapa koloni kecil yang baru tampak pada kultur hari ke-5. Hal ini diduga enzim kolagenase tipe I belum bekerja secara optimum dalam memecah kolagen (Helling et al., 2016), sehingga belum terdapat sel yang -menempel pada cawan petri kultur meskipun viabilitas sel cukup tinggi.

Kultur in vitro dilanjutkan hingga hari ke9 nampak tidak terjadi perkembangan sel yang dikultur pada masing-masing kelompok, selain kelompok perlakuan dengan lama waktu inkubasi tiga jam seperti terlihat pada Gambar 1. Hasil tersebut menunjukkan bahwa waktu optimum inkubasi kolagenase tipe I adalah tiga jam sehingga waktu inkubasi tersebut digunakan pada penelitian tahap berikutnya.

\section{Perkembangan Sel Endometrium Domba dengan Penambahan Hormon Estradiol dan/atau Progesteron}

Hasil penelitian menunjukkan adanya perbedaan yang signifikan $(\mathrm{p}<0,05)$ terhadap tingkat proliferasi sel pada pemberian hormon E2 dan/atau P4 dibandingkan dengan kontrol $(1,62 \pm 0,13)$. Kemampuan proliferasi sel endometrium paling tinggi ditemukan pada sel yang dikultur dalam medium yang ditambahkan $100 \mathrm{pg} / \mathrm{mL}$ estradiol tunggal $(2,49 \pm 0,12)$. Hasil serupa juga menunjukkan perbedaan yang nyata $(p<0,05)$ pada sel yang dikultur dalam medium yang ditambahkan $100 \mathrm{pg} / \mathrm{mL}$ estradiol yang dikombinasikan dengan $10 \mathrm{ng} / \mathrm{mL}$ progesteron $(2,34 \pm 0,24)$, meskipun tidak sebaik pada pemberian E2 tunggal. Sebaliknya, penambahan $100 \mathrm{ng} / \mathrm{mL}$ P4 tunggal dalam medium tidak menunjukkan induksi proliferasi sel endometrium $(1,83 \pm 0,12)$. Hal yang hampir sama juga terlihat pada pemberian $100 \mathrm{ng} / \mathrm{mL} \mathrm{P} 4$ yang dikombinasikan dengan $10 \mathrm{pg} / \mathrm{mL}$ E2 $(1,97 \pm 0,18)$. Meskipun peningkatan proliferasi terjadi secara signifikan $(\mathrm{p}<0,05)$ jika dibandingkan dengan kontrol $(1,62 \pm 0,13)$, namun tidak berbeda jika dibandingkan dengan perlakuan E2 tunggal. Selanjutnya, tidak ada perbedaan yang signifikan $(p>0,05)$ pemberian hormon E2 dan/atau P4 terhadap viabilitas sel pada masing-masing perlakuan (Gambar 3).

Secara umum hasil penelitian ini dapat menggambarkan kondisi sel endometrium secara in vivo yaitu aktivitas proliferasi sel endometrium akan sangat tinggi pada saat jumlah estradiol naik seperti pada saat proestrus dan estrus, dan akan menurun pada saat progesteron naik seperti pada saat metesterus dan diestrus (Cruchten et al., 2004). Hal ini disebabkan terdapatnya sejumlah reseptor hormon steroid pada nukleus sel-sel endometrium (nuclear receptors) yaitu estrogen receptors $(\mathrm{ERs})$ dan progesterone receptor $(\mathrm{PR})$. Estrogen receptors (ERs) terdiri dari dua bentuk yaitu ER $\alpha$ dan ER $\beta$. Namun, ER $\alpha$ lebih banyak terekspresi pada saluruan reproduksi dan lebih efektif daripada ER $\beta$ dalam merespon estrogen untuk mentranskripsi sejumlah faktor penting pendukung sel (Heldring et al., 2007). Ikatan antara E2 dengan ER $\alpha$ menyebabkan proliferasi sel pada endometrium, seperti yang telah dijelaskan oleh Pan et al. (2006) bahwa ikatan tersebut memicu sintesis minichromosome maintenance protein 2 (MCM2) dan senyawa tersebut berperan untuk mereplikasi DNA pada fase-S dalam siklus sel. Ikatan antara E2 dan ER $\alpha$ pada sel epitel dan sel stroma endometrium juga turut mengekspresikan CCAAT/enhancer binding protein beta $(\mathrm{C} / \mathrm{EBP} \beta)$ yang penting dalam meningkatkan aktivitas mitosis dan aktivitas fase-S pada sel epitel endometrium (Mantena et al., 2006). Selain itu, ikatan antara E2 dan ER $\alpha$ pada sel stroma mengakibatkan terekspresinya fibroblast growth factor (FGF) dan beberapa faktor parakrin lainnya mendukung peningkatan proliferasi sel melalui induksi extracellular regulated kinase (ERK) dan aktivitas ER $\alpha$ pada sel epitel endometrium ( $\mathrm{Li}$ et al., 2011).

Satterfield et al. (2008) memperlihatkan bahwa sel epitel dan sel endometrium domba mengekspresikan sejumlah reseptor progesteron (PR). Namun, pada sapi dan domba, sel stroma endometrium diketahui mengekspresikan PR dalam jumlah yang lebih banyak dibandingkan dengan sel epitel endometrium (Spencer dan Bazer, 2002). Penelitian yang telah dilakukan oleh Chung dan Das (2011) mendapati bahwa kultur sel endometrium yang diberikan P4 tunggal pada mencit tidak menunjukkan efek apapun terhadap peningkatan proliferasi sel endometrium, namun jika dikombinasikan dengan E2 terjadi efek penghambatan aktifitas 
proliferasi sel. Hal ini serupa pada hasil penelitian ini bahwa pemberian hormon $\mathrm{P} 4$ dominan yang dikombinasikan dengan E2 dengan perbandingan 100:10 (1.97 \pm 0.18$)$ tidak menunjukkan adanya peningkatan proliferasi sel. Ray dan Pollard (2012) menunjukkan bahwa P4 akan menyebabkan penghambatan replikasi DNA pada sel epitel endometrium yang sebelumnya diinduksi oleh E2. Ikatan antara P4 dan PR pada sel stroma endometrium akan mengekspresikan Krupple-like transcription factor 4 (KLF4) dan menekan KLF5. Peningkatan KLF4 akan menyebabkan sel epitel endometrium kehilangan MCM2 dan menyebabkan terhambatnya replikasi DNA pada fase-S. Li et al. (2011) menyatakan bahwa ikatan antara $\mathrm{P} 4$ dan PR pada sel stroma akan memicu peningkatan proliferasi sel stroma, namun akan menghambat proliferasi sel epitel endometrium. Ikatan ini menyebabkan ekspresi heart and neural crest derivatives expressed 2 (Hand2) dan sejumlah faktor parakrin lainnya yang akan menghambat ikatan antara FGF dan reseptornya yang terdapat pada sel epitel endometrium.

\section{SIMPULAN}

Waktu inkubasi kolagenase selama tiga jam menunjukkan hasil yang lebih efektif dan penambahan hormon estradiol $100 \mathrm{pg} / \mathrm{mL}$ secara signifikan mampu meningkatkan proliferasi sel endometrium domba yang lebih baik.

\section{SARAN}

Perlu dilakukan penelitian lebih lanjut mengenai kombinasi enzim kolagenase dengan enzim lain untuk mendapatkan sel secara optimal, serta perlu dilakukannya pemisahan antara sel epitel endometrium dan sel stroma endometrium untuk mempelajari lebih mendalam peran hormon estradiol dan progesteron terhadap proliferasi sel.

\section{DAFTAR PUSTAKA.}

Aldarmahi A. 2017. Establishment and characterization of female reproductive tract epithelial cell culture. J Microsc Ultrastruct 5: 105-110.

Alipour H, Raz A, Zakeri S, Djadid ND. 2016. Therapeutic applications of collagenase (metalloprotease): A review. Asian Pac J Trop Biomed 6(11): 975-981.

Bartel C, Tichy A, Schoenkypl S, Aurich C, Walter I. 2013. Effects of steroid hormons on differentiated glandular epithelial and stromal cells in a three dimensional cell culture model of the canine endometrium. $B M C$ Vet Res 9(86): 1-16.

Blitek A, Ziecik AJ. 2004. Prostaglandins F2á and E2 secretion by porcine epithelial and stromal endometrial cells on different days of the oestrous cycle. Reprod Domest Anim 39: 340-346.

Bond MD, Wart WV. 1984. Characterization of the individual collagenases from Clostridium histolyticum. Biochemistry 23(13): 3085-91.

Brosens JJ, Gellersen B. 2006. Death or survival - progesterone-dependent cell fate decision in the human endometrial stroma. $\mathrm{J} \mathrm{Mol}$ Endocrinol 36: 389-398.

Chung D, Das SK. 2011. Mouse primary uterine cell coculture system revisited: ovarian hormons mimic the aspects of in vivo uterine cell proliferation. Endocrinology 152(8): 3246-58.

Cruchten SV, Broeck WV, D'Haeseleer M, Simons P. 2004. Proliferation patterns in the canin endometrium during the estrous cycle. Theriogenology 62(3): 631-641.

Daboor SM, Budge SM, Ghaly AE, Brook SL, Dave D. 2010. Extration and purification of collagenase enzyme: a critical review. Am J Biochem Biotech 6: 239-263.

Diedrich K, Fauser BCJM, Devroey P, Griesinger G. 2007. The role of the endometrium and embryo in human implantation. Hum Reprod Update 13: 365-377.

Freshney RI. 2005. Culture of Animal Cells: A Manual of Basic Technique, Fifth Edition, John Wiley \& Sons, Inc.

Gargett CE. 2007. Uterine stem cells: what is the evidence? Hum Reprod Update 13: 87101.

Gibco, Life Technologies Corporation (US).

Giudice LC. 2003. Elucidating endometrial function in the post-genomic era. Hum Reprod 9: 223-235.

Heldring N, Pike A, Andersson S, Matthews J, Cheng G, Hartman J, Tujague M, Strom A, Treuter E, Warner M, Gustafsson J. 2007. Estrogen receptors: how do they signal and what are their targets. Physiol Rev 87: 90531. 
Helling AL, Tsekoura EK, Biggs M, Bayon Y, Pandit A, Zeugolis DI. 2016. In vitro enzymatic degradation of tissur grafts and collagen biomaterials by matrix metallproteinases: improving the collagenase assay. ACS Biomater Sci Eng 3(9): 19221932.

Huang HL, Hsing HW, Lai TC, Chen YW, Lee TR, Chan HT, Lyu PC, Wu CL, Lu YC, Lin ST, Lin CW, Lai CH, Chang HT, Chou HC, Chan HL. 2010. Trypsin-induced proteome alteration during cell subculture in mammalian cells. J Biomed Sci 17(36): 110.

Hull ML, Prentice A, Wang DY, Butt RP, Philips SC, Smith SK, Jones DSC. 2005. Nimesulide, a COX-2 inhibitor, does not reduce lesion size or number in a nude mouse model of endometriosis. Hum Reprod 20: 350-358.

Ishii K, Suzuki N, Mabuchi Y, Sekiya I, Akazawa C. 2017. Technical advantage of recombinant collagenase for isolation of muscle stem cells. Regenerative Therapy 7: 1-7.

Janzen DM, Cheng D, Schafenacker AM, Paik DY, Goldstein AS, Witte ON, Jaroszewicz A, Pellegrini M, Memarzadeh S. 2013. Estrogen and progesterone together expand murine epithelial progenitor cells. Stem Cells Int 31: 808-822.

Jin YQ, Liu W, Hong TH, Cao Y. 2008. Efficient Schwann cell purification by differential cell detachment using multiplex collagenase treatment. J Neurosci Methods 170: 140148.

Jung H, Yoon M. 2016. Isolation of germ cells from testes of stallions using collagenase and trypsinethylenediaminetetraacetic acid (EDTA). J Equine Vet Sci 43: 82-87.

Kaiin EM, Djuwita I, Yusuf TL, Setiadi MA. 2013. Development of in vitro culture of rat Leydig cells after purification with Nycodenz gradient. Open J Anim Sci 7(1): 75-80.

Kimmins S, Lim HC, Parent J, Fortier MA, McLaren LA. 2003. The effects of estrogen and progesterone on prostaglandins and integrin beta 3 (â3) subunit expression in primary cultures of bovine endometrial cells. Domest Anim Endocrinol 25: 141-154.

Lee KS, Nah JJ, Lee BC, Lee HT, Lee HS, So BJ, Cha SH. 2013. Maintenance and characterization of multipotent mesenchymal stem cells isolated from canine umbilical cord matrix by collagenase digestion. Res Vet Sci 94: 144-151.
Li Q, Kannan A, DeMayo FJ, Lydon JP, Cooke PS, Yamagishi H, Srivastava D, Bagchi MK, Bagchi IC. 2011. The antiproliferative action of progesterone in uterine epithelium is mediated by Hand2. Science 331: 912-6.

Limon J, Cin PD, Sandberg AA. 1986. Application of long-term collagenase disaggregation for the cytogenetic analysis of human solid tumors. Cancer Genet Cytogenet 23: 305-313.

Mantena SR, Kannan A, Cheon YP, Li Q, Johnson PF, Bagchi IC, Bagchi MK. 2006. C/EBPâ is a critical mediator of steroid hormon-regulated cell proliferation and differentiation in the uterine epithelium and stroma. Proc Natl Acad Sci 103: 1870-1875.

Maruyama T, Yoshimura Y. 2008. Molecular and cellular mechanism for differentiation and regeneration of the uterine endometrium. Endocrinology 55: 795-810.

Mulholland J, Winterhager E, Beier HM. 1988. Changes in proteins synthesized by rabbit endometrial epithelial cells following primary culture. Cell Tissue Res 252: 123132.

Nisolle M, Roux FC, Marbaix E, Jadoul P, Donnez J. 2000. Transplantation of cultured explants of human endometrium into nude mice. Hum Reprod 15: 572-577.

Pan H, Deng Y, Pollard JW. 2006. Progesterone blocks estrogen-induced epithelial cell proliferation by inhibition of DNA replication licensing. Proc Natl Acad Sci 103: 14021-6.

Pevet MM, Jongsma HJ, Bruijne J. 1976. Collagenase and trypsin dissociated heart cells: A comparative ultrastructural study. J Mol Cell Cardiol 8: 747-757

Ray S, Pollard JW. 2012. KLF15 negatively regulates estrogen-induced epithelial cell proliferation by inhibition of DNA replication licensing. Proc Natl Acad Sci 109: 1334-43.

Saleh L, Otti GR, Fiala C, Pollhelmer J, Knofler M. 2011. Evaluation of human first trimester decidual and telomerasetransformed endometrial stromal cells as model system of in vitro decidualization. Reprod Biol Endocrinol 9: 1-15.

Satterfield MC, Song G, Hayashi K, Bazer FW, Spencer TE. 2008. Progesterone regulation of the endometrial WNT system in the ovine uterus. Reprod Fertil Dev 20: 935-946.

Senger PL. 2003. Pathways to Pregnancy and Parturition, $2^{\text {nd }}$ Edition. Washington State University Research and Technology Park, Washington. 
Simon C, Martin JC, Pellicer A. 2000. Paracrine regulators of implantation. Baillieres Best Pract Res Clin Obstet Gynecol 14: 815-826.

Spencer TE, Bazer FW. 2002. Biology of progesterone action during pregnancy recognition and maintenance of pregnancy. Front Biosci 7: 1879-98.

Toyoshima T, Matsushita O, Minami J, Nishi N, Okabe A, Itano T. 2001. Collagen binding domain of a Clostridium histolyticum collagenase exhibits a broad substrate spectrum both in vitro and in vivo. Connect Tissue Res 42: 281-290.

Wang G, Johnson GA, Bazer FW. 2000. Isolation, immortalization, and initial characterization of uterine cell lines: an in vitro model system for the porcine uterus. In Vitro Cell Dev Biol Anim 36: 650-65.
Wewer UM, Damjanov A, Weiss J, Liotta LA, Damjanov I. 1986. Mouse endometrial stromal cells produce basement-membrane components. Differentiation 32: 49-58.

Wood GA, Fata JE, Watson KLM, Khoka R. 2007. Circulating hormons and estrous stage predict cellular and stromal remodeling in murine uterus. Reproduction 133: 1035-44.

Worthington, Worthington Biochemical Corporations Lakewood (US).

Yonenaga K, Nishizawa S, Nakagawa T, Fujihara Y, Asawa Y, Hikita A, Takato T, Hoshi K. 2017. Optimal condition of collagenase treatment for isolation of articular chondrocytes from aged human tissues. Regenerative Therapy 6: 9-14.

Zhu H, Hou C, Luo L, Hu Y, Yang W. 2014. Endometrial stromal cells and decidualized stromal cells: Origins, transformation and function. Gene 14: 1-14. 